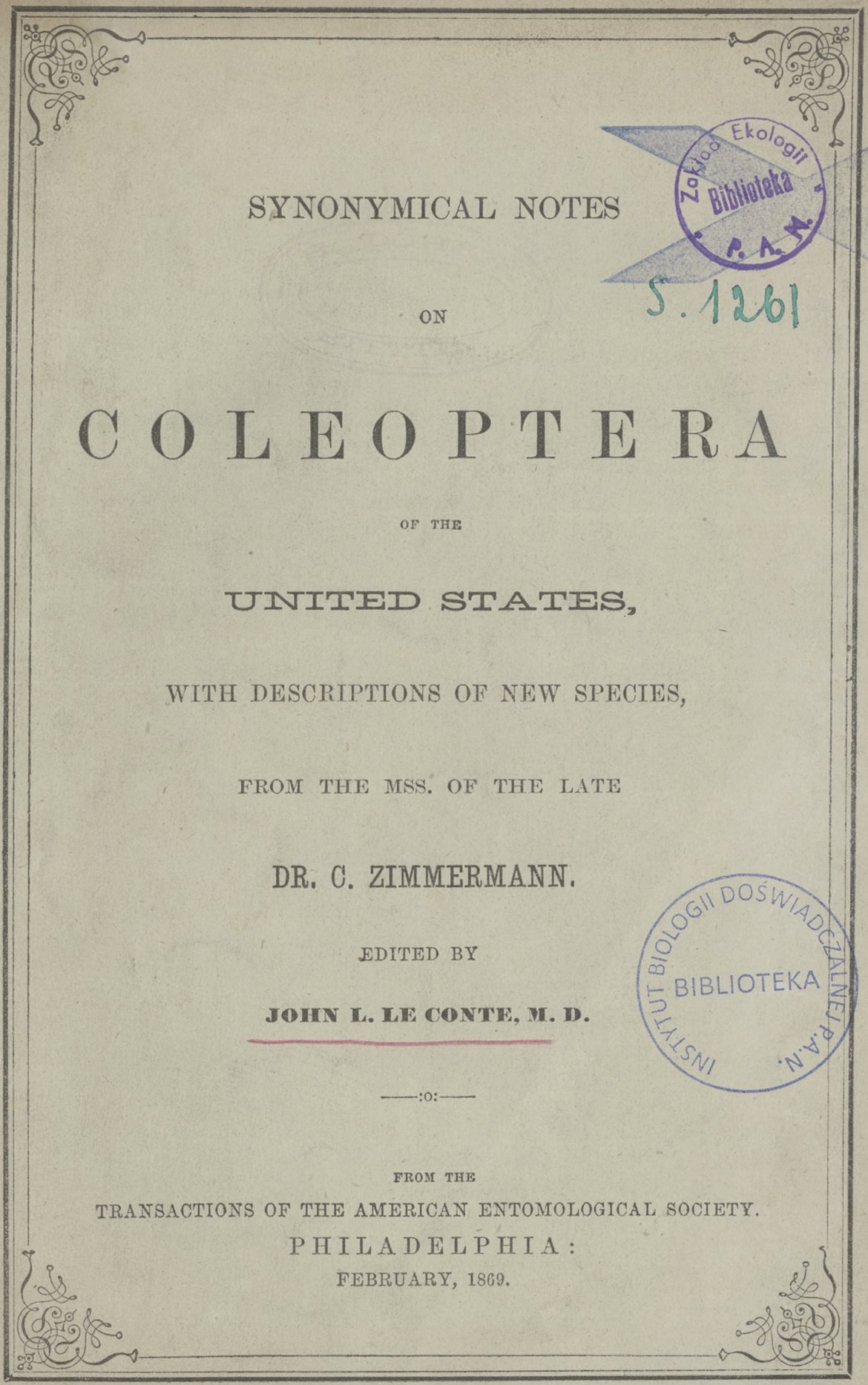

rcin.org.pl 
rcin.org.pl 
[I learn by a recent letter from Baron Chaudoir that this species, from the vicinity of the Rocky Mountains, is not cribricollis Dej. as I formerly regarded it, but one thus far unnamed. Dejean's species is identical with $(C$. marginata Kirby and reflexa Lee., and oceurs in the most northern part of the United States and in Canada.]

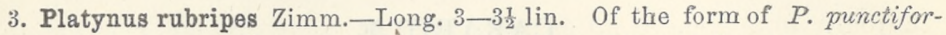
mis, but smaller, with large deep basal impressions of the prothorax, and yellowferruginous legs. Shining black, smooth; palpi and antennæ testaceous, basal joint of the latter yellowish-red. Prothorax almost as long as wide, with rounded hind-angles, near which the broad basal impressions are marked with a small deep fovea. Elytra formed and seulptured as in P.punctiformis, but narrower towards the base, so that the humeri are more angular, while in punctiformis they are rounded.

This insect, omitted by LeConte in his Synopsis of Platyni, or perhaps confused with punctiformis, must be properly received as a separate species. It occurs, but not frequently, in the region north of the Potomac, while the species just named is very abundant in the Southern States.

TThe bad condition of the specimens in my collection prevented me from describing this species as distinct, when I wrote the Synopsis.]

4. Platynus Ienis, (Ag. lenum Dej.) $=P$. retractus Lec.

[The arrangement of the species of Platynus for which, on account of the confusion in the names previously used, Dr. Zimmermann proposed the name Psilopodius, seems so far superior in some respects to that adopted by me, that although I have not had leisure to test it by a re-examination of all my species, I think it well worthy of being presented:]

A. Prothorax cordate, or quadrate, with well defined hind angles; pubescence of antennæ beginning on the 4 th joint:

a. All the joints of the tarsi without longitudinal grooves.--(oblongus of Europe.)

b. Only the front tarsi, $\{$, without grooves.-(Platynus Bon.)

c. All the tarsi with grooves.-(Anchomenus Bon.)

B. Prothorax rounded, or obtuse angled; pubescence of antennre commencing with the 4th joint.-(Agonum Bon.)

d. Prothorax broader than long, with depressed side margins which are reflexed behind.

e. Prothorax broader than long, with narrowly beaded side margins.

f. Prothorax small, elongate oval, with narrowly beaded side margins.

C. (g.) Prothorax rounded, or elongate oval ; pubescence of the antennæ beginning on the tip of the 3rd joint.-(Europhilus Chaud.) 
The species $\mathrm{A}-\mathrm{b}$ group themselves as follows :

a. Winged species with strongly curved claws: (decens, sinuatus, blandus \&c.)

$b$. Winged species with regularly curved claws: (angusticollis of Europe.)

c. Apterous species with regularly curved claws: (angustatus \&c.)

Those of A-c may be grouped thus: according as the tarsi have a middle groove besides the lateral ones, and the mentum tooth is longitudinally impressed at tip, so as to appear slightly divided, or altogether simple and pointed:

Series I. Tarsal joints without medial groove; upper surface of body pubescent :

Group $A$. With lateral grooves on the first three joints of the middle and hind tarsi :

a. Mentum tooth broad, obtuse, and simple.-(Orthotrichus Peyr.) (P. cymindoides of Egypt.)

Series II. Tarsal joints without medial groove ; upper surface of body glabrous :

Group $A$. Lateral grooves of the first three joints of middle and hind tarsi always evident:

a. Mentum tooth somewhat cleft.-(bicoloratus Zimm.=bicolor $\|$ Lec.; brunneomarginatus.)

b. Mentum tooth smooth and simple.-(extensicollis, decorus.)

Group B. Lateral grooves of all the tarsi very feeble, in some specimens not apparent:

a. Mentum tooth smooth and simple.-(prasinus of Europe.)

Series III. All five tarsal joints with a medial groove; upper surface of body glabrous :

Group $A$. First four joints of hind and middle tarsi with lateral grooves:

a. Elytra with 3 dorsal punctures.-(funebris Lec.)

b. Elytra with 2 dorsal punctures.-(albipes of Europe.)

The species of division $\mathrm{B}-\mathrm{d}$ have for the most part only lateral grooves on the basal joints, though sometimes the middle groove is also present. By this character and by the form of the claws, aided by the color of the elytra, they may be grouped as follows:

Series I. Tarsi with a medial groove; claws regularly eurved:

Group $A$. First three joints of middle and hind tarsi with lateral grooves:

a. Elytra with three dorsal punctures.-(subcordatus Lec.)

Series II. Tarsi without medial groove; claws regularly curved;

Group $A$. First three joints of middle and hind tarsi with lateral grooves; elytra margined with yellow:

a. Elytra with 4 or more dorsal punctures.-(maculicollis, variolatus.)

b. Elytra with only 3 dorsal punctures.-(marginatus of Europe.)

Group $B$. First three joints of middle and hind tarsi with lateral grooves, elytra without yellow margin :

a. Elytra with 4 or more foveæ on the 3rd interval.-(8-punctatus.)

b. Elytra with 4 or more dorsal punctures.-(deplanatus, placidus, chalceus.s.)

c. Elytra with 3 dorsal punctures.-(excavatus, cupripennis, metallescens.) 
Group C. First four joints of middle and hind tarsi with lateral grooves; elytra without yellow margin:

a. Elytra deeply striate, with 4 or more dorsal punctures.-(fossiger.)

b. Elytra deeply striate, with 3 dorsal punctures, the 1st and 2nd near the 3rd stria.-(melanarius, lavis.)

c. Elytra finely striate, with 3 dorsal punctures, the 2nd and 3 rd near the 2nd stria.-(collaris, Harrisii, dixianus *Zimm.)

Series III. Tarsi without medial groove; claws bent somewhat backwards. (Sericoda Kirby, Rhytiderus Chaud.)

Group $A$. Lateral grooves of tarsi very faint, sometimes visible only on the basal joint :

a. Elytra with 3 dorsal punctures.-(obsoletus.)

b. Elytra with foveæ on the third interval.-(bembidioides, stigmosus.)

The species of division $\mathrm{B}$-e have but three dorsal punctures, which in general are not connected with the striæ, but stand free upon the 3rd interval; but few are thus far known, which may be grouped thus: Series I. Tarsi without medial groove:

Group A. Tarsi without distinct lateral grooves.-(limbatus.)

Group B. First three joints of middle and hind tarsi with fine lateral grooves.-(punctiformis, rubripes Zimm.)

Division B-f presents no special characters for grouping the species, of which æruginosus and striatopunctatus may be taken as examples.

In the species of $\mathrm{C}-\mathrm{g}$ the lateral grooves of the first three joints of the middle and hind tarsi are visible, but finer than usual; according to the form of the prothorax the following groups are indicated:

a. Prothorax nearly quadrate, or feebly cordate, with distinct though obtuse hind angles.-(micans \&c. of Europe.)

b. Prothorax rounded oval, without distinct hind angles.-(lenis, picipennis, lutulentus.)

Dic ALus.-The species may be arranged as follows :

A. Upper surface violet, or copper colored:

a. Left mandible with a tubercle on the inner margin;-1. purpuratus ; 2. chalybeus; 3. violaceus, (cyaneus Dej. confusus Lec.); 4. iricolor Lec. 5. splendidus.

B. Upper surface pure black:

b. Both mandibles without tubereles.

a. Elytra deeply striate, 2nd, 4 th and 6 th interval interrupted by annular punctures: 6. sculptilis.

b. Elytra deeply striate, all the intervals smooth: 7. dilatatus (of which Dejeanii is a larger Southern race,) 8. elongatus.

c. Left mandible tuberculate at the middle: 9. furvus.

d. Right mandible tuberculate on the outer margin: 10. teter. 11. politus Dej. (Leonardi Harris.)

[* I think this is merely an individual variation of moerens Dej.] 
[I would observe in addition, that while $D$. Trvipennis has the upper surface tinged with violet it differs from all the other species, not only by the feebly striate elytra, but by the labrum being much less emar. ginate; both mandibles are without tubercles; the names attributed to Nos. 8 and 9 do not seem to agree with my determinations of the same species.]

Feronia carbonaria Dej. Sp. Gen. iii, 283.-LeConte has twice mistaken this species: 1st he placed it (Ann. Lyc. iv, 336) as synonymous with caudicalis Say, which is an Hypherpes, and afterwards, (Journ. Ac. Nat. Sc. Phil. 2nd, ii, 243) as luctuosa Dej, which is equivalent to P. abjectus Lec.

[The name carbonaria has been inadvertently omitted in my List, and it is really a synonym of muta Say, as determined by Baron Chaudoir (vide infra); the confusion in my mind with regard to $F$. luctuosa Dej., which as I was afterwards informed by Baron Chaudoir (Say's Entom. Writings, ed. Lec. ii. 480) is the same as my P. aljectus, resulted from the fact that the description of Dejean will apply equally to both species; carbonaria cannot be referred to the present species since the description states that the outer stria of the basal impression is wanting; it is in caudicalis short, and very close to the carina of the angle, which is more distinctly defined than in the smaller species, $P$. luctuosus. About F. caudicalis Say, I may observe that Dr. Harris gave me specimens of the species under consideration, as having been compared with Say's type; moreover the expression "space of the basal angles depressed and punctured," and the fact that the insect is winged, absolutely forbid the reference of Say's description to any species of Hypherpes. The synonymy as printed in my List is therefore correct.]

Selenophorus parumpunctatus Dej. iv, 104. [This species, described by Dejean as being perhaps from the West Indies, has been identified by Dr. Zimmermann as the common small Southern species, S. faturs Lec., New Spec. Col. (Smiths, Inst.), 17.]

0chthedromus pardalis Zim. $=0$. laticollis $\|$ Lec. Ann. Lyc. Nat. Hist. New York, v, 187.' California.

Ochthedromus littoralis.=Carabus litt. Panzer, Fauna, 40, 6. Elaphrus rupestris Fabr. \&c. Bembidium andrece Er. \&c. B. tetracolum Say.

Ochthedromus plagiatus Zim.-Length 2 lines. Somewhat larger than $O$. niger, but of the same general form; dark-green, black beneath; mouth, base of antennæ, and legs ferruginous-yellow ; frontal grooves parallel, simple, deep; prothorax cordate, strongly narrowed behind, with rectangular hind angles, rugosely punctured at the hind margin, with deep basal impressions, and distinct carina at the angle. Elytra convex, much broader than the prothorax, with 7 strongly punctured dorsal striæ, which are obliterated behind, and marked in front of the tip with a large common reddish-yellow oblique spot.-Maryland. 
[Seems to resemble B. bimaculatum but is smaller; $B$. gelidum is also related to it but is much more slender and smaller.]

Ochthedromus lacunarius Zim.-Length $2 \frac{1}{2}$ lines. Piceous with slight metallic lustre; palpi, antennæ and legs ferruginous; head elongate, with deep frontal grooves, and tolerably flat eyes. Prothorax short cordate, very smooth, strongly narrowed behind, with rectangular hind angles; basal impressions deep, with a sharp carina near the angle, but not punctured at the middle; elytra with 6 punctured dorsal striæ, of which only the sutural reaches the tip; the 7 th stria is entirely wanting, but the 5 th becomes again distinct at the tip, and therefore appears interrupted.-Middle States. [I have determined this species, probably incorrectly, as Peryphus picipes Kirby, but fortunately without publishing any remarks which can confuse the synonymy.]

0chthedromus assimilis. $=$ Bembidium ass. Gyll., Dej, \&c.=0. frontalis Lec. Ann. Lye. Nat. Hist. N. York, iv, 462.-Europe and North America.

TAchys. [Several species are described in the MSS. of Dr. Zimmermann, but I have not leisure to collate them with those recently described by Baron Chaudoir, Rev. and Mag. de Zoologie, 1868. In consequence of the descriptions of the species being scattered through several works, some of which are of difficult access, a synopsis of them would be very useful.*]

* This would appear a convenient place to record some interesting and important remarks on the synonymy of North American Carabidø recently communicated to me by Baron Chaudoir, with the kind permission to make such use of them as I judged best for the interest of science.

1. Lebia cupripennis Boheman.= cupripennis Chaud; not Californian, but found in Peru and Chili.

2. Lebia cyanella Motsch.=smaragdina Dej.

3. Lebia marginicollis Dej.=affinis Dej.

4. Lebia ornata Say, type and Var. a.=axillaris Dej.

5. Løbia ornata Say, var. $\beta .=$ analis Dej. (head corrugated.)

6. Lebia marginella Dej.=axillaris, (immaculate variety.)

7. Løbia nigripennis Dej. is not a variety of collaris Dej.

8. Lөbia cyanea Dej.=smaragdina Dej. (blue variety.)

9. Cymindis reflexa Lec.=-cribricollis Dej.

10. Cymindis cribricollis $\$$ Lec. is a very distinct new species near laticollis. (vide supra.)

11. Cymindis venator Dej. My two specimens are much larger than americana, and the prothorax is not at all narrowed behind.

12. Callida cyanipennis Chaud. = smaragdina Dej.

13. Agonum nitidulum Dej.=cupripenne (dark colored variety.)

14. Agonum brevicolle Dej.=Platynus frater Lec.

15. Agonum cupreum Dej. $=A$. chalceum Lec.

16. Agonum striatopunctatus Dej.=O. crenulatus Lec.

17. Agonum decipiens and striatopunctatum $\neq$ Lec. belong to another spscies.

18. Agonum octocolus Mannh.=stigmosus Lec.

19. Agonum sordens Kirby. $=P$. retractus Lec.

20. Agonum lenum Dej.=picipenne Kirby, var $c$.

21. Omaseus fuscoceneus Chaud.=riparius, (pale variety.) 


\section{HYDROPHILID A.*}

Herophorus.-The species of this genus may be grouped as follows :

A. Second joint of hind tarsi obviously longer than the 3rd; elytra without scutellar stria.-(e. g. lineatus and all other N. American species except scaber.)

B. Second joint of hind tarsi obviously longer than the 3rd ; elytra with distinct scutellar stria near the suture.-(e. g. grandis of Europe.)

C. Second joint of hind tarsi not longer than the $3 \mathrm{rd}$; elytra with distinct scutellar stria near the suture.-(e. g. scaber.)

Hydrochus impressus Zimm.-Long. $1 \frac{1}{3}-1$ 2 lines. Above coppery green or blackish, beneath brown; prothorax broader than long, shallowly foveate, deeply but not confluently punctured; intervals of the elytra slightly convex, almost as wide as the striæ, 5 th depressed at the middle, but both in front of, and behind the impression elevated, as is also the 4 th opposite to the impression. Carolina. [A distinet species near variolatus Lec. but among other differences with wider and less deeply impressed prothorax.]

Hydrochus vagus Lec.-Specimens of this species undistinguishable from those collected in California have occured in South Carolina.

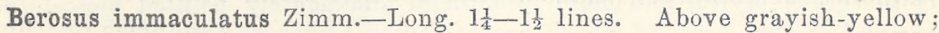
beneath and legs ferruginous-yellow; head and two spots on the front margin of the prothorax metallic-green; mouth and clypeus yellowish. Smaller and narrower than [aculeatus Lec.], with the head and prothorax more equably punctured; front with a shallow fovea, and no posterior elevated longitudinal line; elytra immaculate, pointed behind, with the striæ and intervals distinctly punctured.-Carolina. [Also found in Illinois.]

Hydrophilus nimbatus Say.-Differs from the South American lateralis Fabr.; the yellow side margin is narrower and does not extend upon the front margin of the prothorax; the hind tibiæ are often almost entirely testaceous, the elytra very finely, but visibly striate, and the anal tooth long and sharp, (in lateralis scarcely visible).

[If this determination be correct, as I have no reason to doubt, with the specimens before me, then the Californian $H$. limbalis approaches more nearly to the Brazilian lateralis in the yellow margin being wider

22. Feronia carbonaria Dej.=muta Say.

23. Myas cyanescens Dej.=foveatus Lec. and not coracinus Say.

24. Cratocara Lec. $\doteq$ Polpochile solier. = Melanotus $\|$ Dej. The name given by Solier should be adopted, in preference to the two others.

Upon these synonyms, which constitute a most important addition to our bibliography, since they dispose of many doubtful or unknown species mentiuned in my List, I have merely to observe that they differ in three instances (Nos. 19, 20 and 22) from the determinations of Dr. Zimmermann as contained in the MSS. above printed, but must be regarded as entirely final and conclusive, having been founded upon actual comparison of typical specimens, while the results both of Dr. Zimmermann and myself were obtained from the study of descriptions, often perhaps too imperfect or ill-defined to be of much value.

* No reference is here made to the MSS. relating to Dytiscidæ and Gyrinidæ, as I am now occupied in preparing special memoirs upon those families.-LEc. 
and more or less extended along the apical margin of the prothorax, but recedes from it and agrees with our nimbatus in the small cusp near the tip of the last ventral segment (anal tooth) being prominent and acute.]

Hydroporus striolatus Lec. $=$ H. lateralis $\ddagger$ Herbst. [This synonymy is correct, and that printed in my List is wrong. I

Hydrocharis grandis Zimm.-Long. 8 lines This species differs from caraboides and obtusatus by the elytra being more pointed behind, with the rows of punctures extremely fine, not becoming more obvious towards the tip, as is the ease in each of those species.-South Carolina. [But two elytra remain of this species, which seems quite distinct by its greater size.]

Philhydrus pygmæus. $=$ Hydrophilus pygm. Fabr. Ent. I, 186. $=H$. nebulosus Say, Long's Exp. 2, 277.

Philhydrus reflexipennis Zimm.--Long. 1운-2 lines. Elongate oval, yellowish-brown, beneath blackish, upper surface very distinctly and thickly punctured; elytra behind with strongly depressed, almost reflexed margin.-New Jersey. [Very closely allied to H. perplexus Lec., but smaller, with more strongly margined elytra, and more prominent and acutely pointed mesosternal carina.]

Philhydrus nitens Zimm.--Long. 2x lines. Black, margined with yellow, beneath and legs brown; form size and color as in H. cinctus, but the upper surface is more feebly punctured, and very shining; the mentum is shorter and broader, and the prominence of the mesosternum short and placed transversely.-North Carolina.

Philhydrus semistriatus Zimm.-Long. 13-2 lines. Black, prothorax and elytra margined with ferruginous-yellow, body oval, distinctly punctured, elytra towards the tip distinctly punctate striate.-Maryland. [In this species too, the mesosternum is not carinate, but transversely prominent.]

Cyclonotum semiglobosum Zimm.-Long. 1-1 - 1 lines. Shining black, palpi and feet testaceous; head and prothorax almost smooth; elytra distinctly and thickly punctured, without any striæ.-Carolina. [This species is allied to estriatum, but differs by its broader and more rounded form.]

Cereyon naviculare Zimm.-Long. $\frac{2}{3}$ line. Black, with a slight bronzed reflexion, shining, reddish translucent at the suture and side margin of the elytra; palpi, antennæe and legs yellow; prothorax smooth, side margins somewhat converging in front; elytra very evidently compressed, pointed behind, finely punctured, with 11 fine rows of punctures becoming indistinct towards the tip, suture elevated behind.-Middle States.

Cercyon melanocephalum. $=$ Dermestes melan. Linn. $=$ Sphaeridium apicialis Say, Jour. Acad. Nat. Sc. iii, 203.

Cercyon pygmæum. =Sphoridium pygm. Illiger. Found both in Europe and North America.

\section{RHYPOPHAGA.}

Cyrtusa blandissima Zim.-Long. $\frac{3}{4}$ line. Ferruginous, shining; front finely punctured; prothorax behind not wider than in front, somewhat emarginate at tip, with the sides slightly deflexed, but only feebly rounded, the front angles therefore are nearly rectangular, disc feebly impressed and very finely punc- 
tured both before and behind. Elytra with tolerably coarse rows of punctures, the sutural stria more deeply impressed; pectus distinctly and thickly punctured.-North Carolina.

Cyrtusa impubis Zim.-Long. $\frac{2}{3}$ line. Much smaller than the preceding species, broadly elliptical, very convex, ferruginous, smooth, shining; prothorax entirely smooth, at tip feebly emarginate, narrowed in front, side margins not deflexed, and therefore between the obtuse front and hind angles more rounded than in the preceding species. Elytra with very fine rows of punctures, which are almost obliterated in front. Pectus finely punctured.-North Carolina. [Mr. Ulke has found this species in the District of Columbia..]

Toxidium compressum Zim.-Long. ${ }^{3}-\frac{7}{5}$ line. Of the same form and color as gammaroides, and equally smooth above, but somewhat smaller, and still more compressed, and easily distinguished by the coarse punctures of the pectus. The structure of the prothorax is very singular, the side margin is slightly prominent and carinate in front, but behind the middle, is pressei closely to the body, and therefore the impressed line of the marginal bead disappears, the margin itself where it meets the epimeron of the mesothorax forms an distinct angle, and causes the hind angles, which would otherwise be acute, to appear rounded.-Louisiana. [I have specimens of this species from Texas, Florida and Illinois.]

Scydmænus mississipicus Zim.-Nearly 2 lin. long. Ferruginous-brown, very shining, and smooth, although tolerably thickly clothed with hair, the head especially thickly covered behind with erect hairs; prothorax not longer than wide, narrowed in front, with slight transverse impressions behind, in which four deep foveæ are visible; elytra with one longitudinal impression in front near the suture, and a fovea near the sharply defined humeral carina; front thighs much thickened, front tibiæ strongly compressed towards the tip, and on the inner side furnished with a brush of hairs.

[The MS. of Dr. Zimmermann relating to the Seydmænidæ is prefixed by a brief treatise upon the classification of the RнүрорнаGA, from which the following extracts are made, with the expectation that the suggestions contained therein may be useful to other students. After reviewing the relations in which the families of the series have been placed by Erichson, Lacordaire, Redtenbacher, Duval, and the editor, he proceeds to eliminate and transfer the following families: the Pselaphidæ, Claviger, and Staphylinidæ to form another series, BRACHELyTrA; the Phalacridæ and Telmatophilidæ to the series CordyloCERA; the Rhyssodidæ, Passandridæ and Cucujidæ to the series Isomera (Xenomorpha), and also the Georyssidæ, Parnidæ, and Heteroceridæ, to the series PHILydria. The families of Rhypophaga are then distinguished as follows:]

A. Wings membranous, with distinet veins, and mostly suitable for tlight; ventral segments 5 or less in number :

a. Ventral segments 4 ; tarsal joints variable in form and length,......Paussidæ.

b. Ventral segments 5 ; tarsal joints narrow :

Hind coxæ not excavated for the reception of the thighs; pygidium always exposed,

Histeridæ. 
Hind coxæ not excavated for the reception of the thighs; pygidium not exposed Mycotophagidæ.*

Hind coxæ excavated for the reception of the thighs,............Dermestidæ.

c. Ventral segments 5 ; first 3 joints of the tarsi dilated, Nitidulidæ + B. Wings membranous, with distinet veins, and mostly suitable for flight, but in some genera wanting, or undeveloped; ventral segments $b$ or more in number :

a. Elytra with distinct veins Silphidæ.

b. Elytra without veins ;

Prothorax shield shaped, with sharply defined side margins...Anisotomidæ. Prothorax rounded or cylindrical, without margined sides......Scydmænidæ.

Platysoma æquum Lec. N. Sp. Col. 1, 61.-This is the Hister frontalis \| Say, which would with difficulty be recognized from Say's description unless a specimen were present (in natura) for comparison. The body is parallel in form, black, the antennæ and legs red, the club of the antennæ ferruginous, the front is flat, not impressed, thickly and finely, though quite distinetly punctured, with the anterior part raised above the clypeus, and surrounded by a fine marginal stria; the clypeus is therefore very short, (or as Say has expressed it, linear 3 ). Prothorax transverse, quadrate, thickly punctured, with distinct marginal stria, which extends along the front margin, and with a small basal fovea at the middle. The elytra have 6 entire dorsal striæ, and no lateral stria; the epipleuræ are flat, narrow, scarcely punctured; pygidium and propygidium coarsely punctured; the middle of the under surface thickly and finely punetured; mesosternum not margined in front; front tibiæ 4-toothed. [I failed to recognize Say's species in this remarkable insect, believing with my father that we had determined it in another which more nearly resembles in form $P$. parallelum with which Say compares it.]

Hister servus Er.-Very similar to indistinctus Say, but easily distinguished by the pygidium which is very coarsely punctured.-Maryland, Cuba, Hayti. [Not before noted as occuring in the United States.]

Hister permixtus Zim.-Long. $1 \frac{1}{2}$ line. Also an allied species to servus, very similar to indistinctus, but entirely of a brown color, and distinguished by the following characters: exterior stria of prothorax abbreviated or interrupted at the middle; marginal stria of the elytra deeper and dilated in the form of a fovea, (grubenförmig); pygidium sparsely and very finely punctured; front tibiæ 4-toothed, the lowest tooth broadly divided.-Carolina.

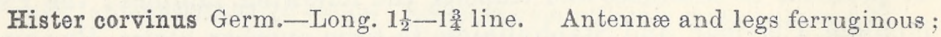

* Here belong also the Colydiidæ, Cryptophagidæ, Trogositidæ, Peltidæ, Thorictidæ, Mycetæidæ, Murmidiidæ, Lathridiidæ, Monotomidæ, Derodontidæ, and Othniidæ of other authors.

† Including Byrrhidæ and Throscidæ.

¥ [This table, although written recently, appears to be partly provisional; in another MS, the Nitidulidæ are placed near the Phalacridæ, Eumorphidæ, Erotylidæ and Coccinellidæ in the series "Kolbenkäfer," Cordy Locera-Lec.]

3. In a transverse direction; this peculiar conformation of head results from the fact, that the elevated margin, under which the antennæ are inserted, is prolonged transversely just in front of the frontal stria, instead of forming the side margin of the clypeus, producing thereby such a depression of the latter. as is observed in most of the species of the genus. 
four exterior dorsal striæ of the elytra entire, the two inner ones abbreviated in front; the inner lateral stria only rudimental, or entirely absent. I found this European species also in South Carolina. [Not before noted as occurring in America.]

Carcinops lautus Zim.-Long. $\frac{3}{4}$ line. Oval, convex, very shining piceous, antennæ and legs ferruginous; head and prothorax finely sparsely punctured, punctures of different sizes; marginal stria of prothorax very fine, scarcely obvious in front; elytra with the sutural stria feeble, composed only of separate punctures, and abbreviated in front, five dorsal striæ entire, slightly curved inwards, and distinctly punctured; the inner lateral stria is well developed, and finer than the dorsal striæ; pygidium and propygidium smooth; mesosternum deeply emarginate in front, and surrounded by a fine stria; front tibiæ 2-toothed.-North Carolina.

Carcinops troglodytes Mars.-[Under this name he notes the species which is not uncommon in the Southern States, and which is usually regarded as Paromalus pumilio Er.]

Echinodes Zim.-An intermediate form between Eretmotus and Hetærius, and easily distinguished from the latter by the large, long, broad, and concave mental lobe, (Kinnlappen).

E. setiger.=Hetcerius setiger Lec. Proc. Acad. Nat. Sc. Phil. 1859, 316.-I found this insect on April 13th, in the nest of a small brown ant at Columbia, S. Carolina.

Pachylopus Er.-These insects differ from Saprinus by their incrassated thighs, and by the club shaped, thickened middle and hind tibiæ being densely clothed with spines. In the form of the head they agree with the first division of Saprinus; the prothorax is large and smooth, or at least only punctured along the hind-margin.

The following divisions may be established:

A. Upper surface smooth :

a. Prosternum forming a strong acute keel.-( $P$. dispar, Africa. $)$

B. Upper surface punctured:

b. Prosternum strongly carinate, margined only near the base, which is broader.-( $P$. sulcifrons, serrulatus.)

c. Prosternal striæ equally apparent at the base, but converging at the middle into a longitudinal line.-( $P$. palmatus.)

d. Prosternal striæ closely approximate, but separate to the apex.-( $P$. dimidiatus of Europe).

Epierus novellus Zim.-Long. 1 line. Smaller and narrower, and more parallel in form than nigrellus, piceous, with ferruginous antennæ and legs, very finely and thickly punctured, somewhat more coarsely upon the prothorax than the elytra; the striæ entire, fine but well impressed, and also regularly curved; the two inferior marginal striæ feeble and slightly punctured; pygidium flat, and like the propygidium, thickly and strongly punctured.-Carolina.

Epierus planulus Er.-Columbia, Mexico, California. LeConte has discribed (Ann. Lyc. Nat. Hist. New York, V, 164) this species under the vame decipiens. The order of names given in his List, p. 28, is incorrect. [By a typographical error the synonym decipiens has been placed ofter vicinus Lec. instead of planulus Er. 
Paromalus affinis Lee.-Usually larger than aqualis, and more narrowed behind; easily distinguished by the pygidium, which is larger and more convex, sculptured only with fine reticulated aciculate lines; these are especially obvious in the male, but in the female are less marked, and sometimes entirely wanting. In both sexes of cequalis the pygidium is alike, and covered with coarse tubercles and deep rugosities.

Plegaderus Erichsonii Lec., List of Col. N. Am. (Smiths. Inst.) p. 28. $=P . p u-$ sillus $\ddagger$ Lec. Bost. Jour. Nat. Hist.-Less than $\frac{1}{2}$ line long. Pale or dark piceous, with ferruginous antennæ, and reddish-brown legs. Head and prothorax finely punctured, the latter with a deep lateral impressed line, and convex elevated margin, dise without transverse groove, but in place of it, in certain lights, a very faint transverse impression may be observed; elytra distinctly punctured, and with very fine and short hairs. Abundant in Carolina, in November under pine bark.

The species of Plegaderus may be divided into three groups :

a. Disc of prothorax with a deep transverse groove, and the prosternum with a patch of hair.-(Most of the species, including transversus.)

b. Disc of prothorax without transverse groove, but prosternum with a patch of hair.-(Erichsonii.)

c. Disc of prothorax without transverse groove, and prosternum without patch of hair.-(pusillus of Europe.)

Aulonium ferrugineum. *-Length $1 \frac{1}{2}$ line. Ferruginous, more slender than parallelixipedum; head distinctly punctured, with two elevations on the front, and one fovea. Prothorax much longer than wide, and as well as the elytra, very finely and sparsely punctured; the two inner longitudinal ridges are strongly elevated, and extended in a tooth like prolongation over the apical margin which therefore appears emarginate; the intermediate spaces on each side of the middle striæ are convex, the middle striæ approach each other in front and diverge curvilinearly behind; elytral rows of punctures very fine.-Carolina.

[Lasconotus] referendarius Zim,-Length almost 1 line, somewhat narrower than [pusillus Lec.], colored, punctured and pubescent in the same manner, but quite different in the prothorax. The dorsal costæ are in fact ill-defined, and only faint traces of two fine lines can be perceived in the deep longitudinal impression; on the elytra the 4 costæ next the suture are distinctly elevated, the first costa reaches the tip, the fourth is obsolete in front; between the custæ are two rows of coarse punctures.

Colydium lineola Say.-Probably longiusculum Say is not different from this species, from which it ought to differ by the absence of the medial dorsal line of the prothorax; since no other author mentions such a species, we might suppose that its description by Say has originated in some error.

Procyctus Zim.- - [Under this name he establishes for Bothrideres exaratus Mels., a separate genus, having the following characters.] 'These insects differ from the genuine Bothrideres, with which they are often confused, by the short thick head, and transversely elongate

[* No extracts from the MS. of Nitidulidæ are here made, because a Monograph of the family by Mr. A. Murray is now in progress.] 
eyes. The prothorax and elytra are furnished with longitudinal costæ, but the antennæ, palpi, coxæ, and terminal spine of the front tibiæ are as in Bothrideres

Mrchocerus Er.-Very small insects, which in external structure have a general resemblance to Cerylon, but with the head so deeply retracted into the prothorax, that the genus eannot be properly referred to the same tribe, but must rather be reckoned as belonging to a separate tribe of the same family, Dermestid a.

The clypeus is separated from the front by an evident suture; the mandibles, palpi and labrum very short; the first two joints of the antennæe are thick, the 10th forms* a rounded club, received in a deep fuvea of the prothorax; the latter is transverse, and shaped almost as in the Anthreni; scutellum very small. Elytra covering all the dorsal segments. Under surface flat, with broad sterna, and therefore all the coxæ widely separated; the prosternum separated from the lateral depressed parts by a longitudinal carina, prolonged in front so as to cover the mouth; first ventral segment as large as the other four together; tarsi slender 4-jointed.

M. [depressus.=Murmidius depr. Lec. Proc. Acad. Nat.Sc. 1866, 376.] Length $\frac{1}{2}$ line. Elliptical, slightly convex above, ferruginous, with yellow legs; under a high lens the upper and under surface appear very finely punctured, and covered with fine pubescence. Prothorax transverse, twice as wide as long, with obtuse front angles, upon which the antennal foveæ are situated; the hind margin forms an obtuse angle at the middle, from which to the sides it is feebly emarginate, the hind angles are acute, the sides converge obliquely in front, flat, not deflexed, very finely margined, somewhat impressed near the hind margin. Elytra very distinctly punctate-striate, in front as wide as the prothorax, and closely affixed to it, behind rounded.-South Carolina.

[I have been thus particular in translating the whole of Dr. Zimmermann's description, because on renewed examination of the specimens I find that they differ from Murmidius generically by the antennal foveæ being upon the anterior angle of the prothorax extending below, instead of above them as in Murmidius, in which they occupy the dorsal surface just by the angle. Nevertheless, in comparing the two species before me which represent the two genera, I cannot but be convinced that they are closely allied, and that their affinities are rather with Histeridxe than Cerylon; nor in fact do I perceive any essential generic distinction, apart from the one above mentioned and minor differences in the antennæ, except that the prosternal striæ are more distant, and the anterior lobe less developed in Mychocerus than in Mur-

\footnotetext{
* According to Erichson's description; I have not been able to draw out the antennæ so as to count the number of joints.
} 
midius. The antennæ are well displayed in the two specimens given me by Mr. Ulke, and show that the 1st joint is much broader than the $2 \mathrm{nd}$, though the latter is thicker than the following ones, the 1 st is not so elongated as in Murmidius; the tibiæ are narrower, and the legs somewhat less retractile. The pro- and meso-sternum fit closely together in both genera, precisely as in the Histeridæ, with which in all the characters mentioned they show a strong affinity, and no resemblance at all to Cerylon or its allies.]

Corticaria denticulata Mann., Germ. Zeitschr. v, 23.=Lathridius dent. Gyll. iv, 126.-Common to Europe and North America.

Corticaria serrata Mann. ibid. v, 28.=Dermestes serr. Payk. Fauna. i, 300.= Lathridius serr. Gyll. iv, 126.-Europe and North America. To this species without doubt belong C. denticulata Kirby, Fn. Bor. Am. iv, 110, and Lathr. 8-dentatus Say, Journ, Ac. Nat. Sc. Phila. iii, 325.

Corticara elongata Gyll. iv, 130, (Lathr.)-Europe and North America.

Corticaria pusilla Mann. Germ. Zeitschr. v, 48.-North America, from South Carolina to California.

[This is the species which I described under the name rugulosa; it is very abundant at Lake Superior, but is not found in California, the specimens so labelled in Dr. Zimmermann's collection were sent to him by me, and were collected on point Kewenaw.]

Corticaria villosa Zim.-Length $\frac{3}{4}$ line. Ferruginous, nearly allied to americana, but the head and prothorax are more thickly punctured, and clothed with very short grayish squamiform hairs, the transverse impression of the prothorax is less deep, the elytra with unusually long hairs, and also more densely pubescent on the intervals, so that viewed sideways they appear clothed with a silky covering.

Corticaria subimpressa Zim.-Length $\frac{2}{3}$ line. Ferruginous with brownish elytra; front much broader than in americana, with very fine scattered punctures. Prothorax a little broader than the head, transversely quadrate, moderately convex, very finely punctured, hind margin slightly rounded, hind angles acute, prominent, front angles rounded, dise in front of the base with a feeble transverse impression, which sometimes is scarcely visible, usually however composed of three foveæ of which the lateral ones extend to the side margin, and the middle one appears punctiform. Elytra finely punctate-striate, and in the striæ and upon the intervals furnished with short gray squamiform hairs arranged in rows.- North America.

C. similata and subtilis Mannh. are allied to this species.

Lathridius rugicollis Mannh. Germ. Zeitschr. v, 77.=Ips rug. Oliv. ii, 18, 13, tab. 3, fig. 19.-Europe and North America.

[This is the species I described under the name $L$. reflexus (Proc. Ac. Nat. Sc. Phil. vii, 304.]

Silvanus bicornis Rosenh.-Found both in Europe and America. This speeies closely resembles S. surinamensis in form, color, size and sculpture, and differs only by the elevated side margin of the front terminating anteriorly in a 
small elevated tubercle, or little horn. Since this insect occurs wherever $S$. surinamensis is found, it may be only a variety of the latter, though much less common. Both forms occur in either sex, the males being distinguished in both species by the toothed hind thighs.

Lathropus vernalis Zim.-[This name is given to the species mentioned by me, Proc. Acad. Nat. Sc. Phila. 1866, 379, but the characters by which it is to be distinguished from the European L. sepicola are not pointed out. Comparison of specimens is therefore still necessary.]

Nausibius major Zim.-Length 2-21 lines. Of the same form as $N$. dentatus, but somewhat larger, of black color, with reddish-brown antennæ and legs, and perceptibly more coarsely punctured.-Carolina. This species is found only under the bark of old oaks.

Læmoph?œus testaceus. $=$ Cucujus test. Fabr. \&c.-Europe and North America. [Not before noted as common to the two continents; I described it as L. Zimmermanni.]

Læmophlœus pusillus. $=$ Cucujus pus. Schœnherr. $=$ C. minutus Oliv.-Europe, Africa, North and South America. [Not before noted as occurring in the United States.]

Læmophlœus alternans Er.-Europe and North America. [Not before observed in the United States; neither of these species were in my collection.]

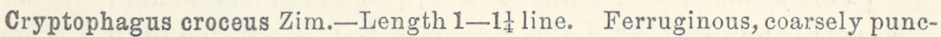
tured, clothed with long hair, moderately broad and convex. Prothorax with the lateral teeth directed more upwards than outwards, therefore appearing less prominent than they really are; the outer surface of the front tooth highly polished, convex and circular; elytra with punctures arranged in rows; antennal club unusually thick.-South Carolina.

Cryptophagus crinitus Zim.-Length $1-1_{4}^{\frac{1}{4}}$ line. Ferruginous, thickly, tolerably strongly punctured, punctures placed without order, pubescence short. On the prothorax only the two front elevations are visible, the side margin is narrowly reflexed and the lateral teeth are very obtuse, the front tooth has a highly polished rounded surface which is impressed in the centre. Elytra with two fine striw each side of the suture, which are abbreviated in front; antennal club unusually thick.-South Carolina [and Illinois.]

Cryptophagus fungicola Zimm.-Length 1 line. Ferruginous, finely and thickly punctured, clothed with prostrate gray hairs; marginal teeth of the prothorax scarcely visible, and the polished spots of the front angle very narrow ; the four elevations and the little fold at the base are quite evident; antennal club small.-Carolina.

[This and the two preceding species belong to the division of the genus in which the prothorax has more or less evident smooth elevations, and a very short elevated ridge at the middle of the base; in the next species no such inequalities of the surface are apparent, and the disc is regularly convex.]

Cryptophagus nodulangulus Zim.-Length 1 line. Ferruginous, very shining, finely and equally but not closely punctured, clothed with prostrate yellow hair; prothorax altogether evenly convex, distınctly bidentate on the sides, the front tooth not planed. down, but convexly protuberant.-Middle and Southern States. 
Atomaria.-The species of this genus are numerous, thus far found only in the northern temperate zone; the following divisions may be recognized :

A. Prothorax with the lateral margin double; 1st joint of the antennal elub conspicuously smaller than the other two:

a. Prothorax feebly bisinuate at base

ferruginea, testacea.

B. Prothorax with single lateral margin; all three of the joints of the antennal elub of nearly equal size:

b. Prothorax feebly bisinuate at base..... ochracea.

c. Prothorax not sinuate at base ephippiata.

Atomaria testacea Zim.-Length $\frac{2}{3}$ line. Ferruginous, smaller than A. ferruginea, more strongly punctured, with the pubescence thinner and shorter; upper surface shining, prothorax distinctly broader than long, with rounded sides and distinet hind angles.-South Carolina.

Atomaria ochracea Zim.-Length $\frac{3}{4}$ line. Rounded oval, ferruginous or pale brown, moderately shining, very finely and thickly punctured and clothed with very short pubescence; head scarcely visibly punctured, prothorax transverse, very convex, in front much narrower than behind, sides rounded; elytra broadest before the middle. I found this species in Maryland, in copula, in September.

Atomaria ephippiata Zim.-Length $\frac{2}{3}$ line. Black, antennæ legs, anus, and ely tra ferruginous yellow, the last with a large black spot, at the middle, which extends from the side margin to the suture, near which it is very much narrowed thus forming an irregular transverse band; upper surface sparsely clothed with fine silvery pubescence.' Prothorax and elytra very convex, so that in a side view the dorsal is as great as the lateral curvature, which is greater in this than in the other species, the puncturing of the prothorax is finer and closer than that of the elytra,-Middle States: [A common species resembling the Californian A. loetula Lec., but larger and more convex, and differently colored.]

Anthrenus museorum.-[Dr. Zimmermann notes this common European insect as found in North America; I have not as yet seen any native specimens.]

Anthrenus adspersus Herbst.-[Dr. Zimmermann considers this species the very common insect generally known as $A$. castanece Mels.]

Hadrotoma Er.-[Dr. Zimmermann refers to this genus the insect described by me as Dearthrus longulus, New Spec. Col. (Smiths. Inst.) 73 , with the remark that the antennae properly consist of but ten joints, which agrees with the description given by Duval, Gen. Col. Eur. ii. 256; I was misled by the original description of Erichson (Ins. Deutschl. iii. 444,) in which this important character is not noticed, and proposed for our native species a new genus.]

Byrrhus.- [In this genus, as defined by Dr. Zimmermann, are included 3 divisions or groups of species, Microchæetes, Syncalypta and Curimus, in which all the tarsi are retractile into tibial groves and the body clothed with erect bristles; a division with 3rd tarsal joint lobed 
or simple, in which no erect bristles are present, but the tarsi are also retractile into tibial groves; and 3rd those in which only the anterior tarsi are retractile, and the tarsi lobed or not, including Cytilus, Morychus and Pedilophorus.]

B. alternatus Say.-Nearly allied to varius, but comparatively longer, or according to its length narrower. Kirby observed the differences between this insect and the European varius; Melsheimer also distinguished it as a separate species; whether the true varius Fabr. is found in America is doubtful.

Stenelmis vittipennis Zim.-Length $1 \frac{1}{4}$ line. Similar to sinuatus, but somewhat broader, and less convex; above blackish-gray, antennæ, tarsi, abdomen, and bead of prothorax, ferruginous; prothorax longer than wide, scarcely narrowed in front, with parallel sides, long and pointed front angles and slightly elevated dorsal costæ; elytra punctate-striate, the inner intervals broader than in sinuatus, 3rd tolerably flat in front, and only the 6 th costiform.-S. Carolina.

Stenelmis linearis Zim,-Length 1 line. Slender, head, prothorax and scutellum dark bronzed; elytra shining black, with a broad yellow vitta, which begins on the humeral angle, then runs inside of the elevated costa of the 6th interval, nearly to the tip; under surface and thighs blackish-gray, with bluish and silvery reflections; antennæ, tibiæ and tarsi ferruginous, front and prothorax with a shining black longitudinal groove; prothorax elongate, scarcely narrowed in front, with very feeble longitudinal ridges; elytra deeply punctate-striate, with the 6th interval feebly elevated; middle tibiæ on the inner side finely toothed at the middle.

Lrmnus.- These species exhibit an intermediate form between Stenelmis and Elmis; from the former they differ by the pubescent spot on the inner side of the tibiæ, from the latter by the round scutellum. In the structure of the elytra, they have the narrow inflexed side margin in common with Stenelmis, but differ in a less degree, since the costiform elevation, which in Stenelmis is always the 6th interval, here belongs to the 5th, (the space between the suture and the 1st dorsal being counted as the 1st interval.)

L. pusillus.=Stenelmis pusillus Lec., Proc. Acad. Nat. Sc. Phila. vi. 44.

Parnus.- [In this genus, as here defined, are included as divisions, Potaminus (Dryops Leach), Parygrus and Pelonomus.]

Psephenus trentonensis Zim.-Length $2 \frac{1}{2}$ lines. Nearly allied to Lecontei, but darker in color, blackish-gray, only the base of the thighs, the tarsi and the inflexed margin of the elytra ferruginous-yellow; prothorax almost semicircular, the sides and apex, without prominent front, forming a common curve; base deeply bisinuate, with flat hind angles.-Trenton Fal's, N. Y.
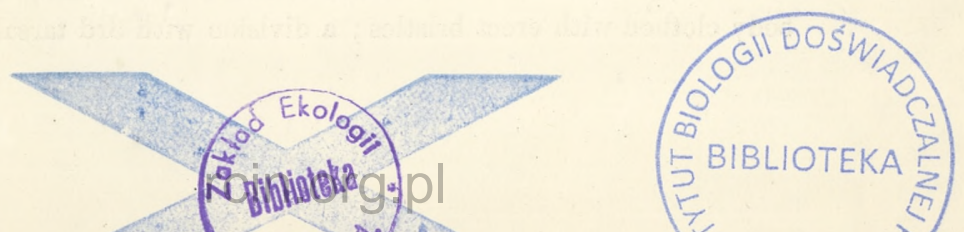
rcin.org.pl 
rcin.org.pl 


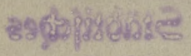

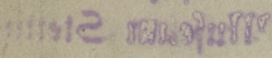

